\title{
Tid og Kræft
}

\section{Rikke Sand Andersen \& Anne Roelsgaard Obling}

Forskningsenheden for Almen Praksis, Institut for Folkesundhed \& Institut for Kultur og Samfund, Antropologi, Aarhus Universitet

Institut for Organisation, CBS

rsa@alm.au.dk

ar.ioa@cbs.dk

Andersen, R. S. \& Obling, A. R. (2014). Tid og Kræft, Introduktion . Tidsskrift for Forskning i Sygdom og Samfund, nr. 20, 5-12

\section{Om begrebet tid}

"Time is durational rather than featureless. It has rhythms. There are rhythms of sacred-profane, and of collective-individual life. These universal characteristics have particular local shapes in particular local ways of life and representations" (Durkheim 1912 i: Miller, 2009: 16)

Durkheim var en af de første sociologer, der anlagde et relativistisk syn på tid. Overordnet påpegede han, at vores forståelse af tid har et socialt udspring, hvor samfundets eller kollektivets perspektiver på tid har betydning for, hvordan det individuelle menneske både kan udfolde sig og opleve verden omkring sig. Inden for antropologien udkrystalliserede dette relativistiske syn på tid sig tidligt som en teoretisk distinktion mellem to forskellige tidsopfattelser: cyklisk tid og lineær tid. I samfund med en cyklisk tidsforståelse er det de sociale, naturens eller de kosmiske begivenheder og ikke tiden i sig selv, der markerer progression eller forandring, og adskillelsen af fortid og fremtid som væsensforskellige er mindre distinkt end i samfund med en lineær tidsforståelse. I modsætning til den lineære tidsforståelser stadfæstes hændelser ofte ved at henvise til andre begivenheder 
end ved en afsondret tidsangivelse. Et eklatant eksempel på den lineære tidsforståelse er den vestlige kalender, hvor tid betragtes som noget fremadskridende, som noget vi lægger bag os, og som altid går lige stærkt. Det er tiden alene, der markerer progression (Nikolaisen 2004).

Der er i dag generel enighed om, at man i de fleste samfund, også her i Vesten, både opererer med en cyklisk og en lineær tidsforståelse, og at den etablerede teoretiske distinktion mellem de to har afsæt i en vestlig kosmologiopfattelse eller distinktion mellem os og dem eller de før-moderne og de moderne (Munn 1992, Gell 1992). Ifølge den amerikanske antropolog Alfred Gell (1992) viser denne kunstige distinktion sig blandt andet i den måde, vi i Vesten forstår og strukturerer vores arbejde på. Vi opererer, siger han, både ud fra rytmiske/lineære og sociale/cyklisk etablerede skemaer. Arbejde udenfor arbejdstid kategoriseres for eksempel anderledes end arbejde udført i arbejdstid og tillægges ligeledes en anden betydning da det "aquire significance against a background of established expetations as to the symbolic character of the hours of the day" (Gell 1992: 108). At arbejde over kan symbolisere travlhed, ambitioner eller dårlig planlægning og er således ikke bare 'tid, der går' eller arbejde, der udføres på et andet tidspunkt af døgnet, men en aktivitet, der potentielt har referencer til både fortid og fremtid. Ifølge den britiske antropolog Edmund Leach har mennesker angiveligt altid forsøgt at forene cyklisk og lineær tid. Vores tankegang baserer sig ifølge Leach, nemlig "på to logisk distinkte, men modsætningsfyldte observationer: For det første noterer vi os, at der er naturfænomener, der gentager sig (fx årstiderne), for det andet, at selve livsprocessen er irreversibel, at vi mennesker og alt levende omkring os fødes, ældes og dør." Leach fremhæver, at skønt det moderne menneske primært opfatter tiden som en irreversibel strøm, så kan det ikke forliges med at livsprocessen er uafvendelig. "»Var det ikke for dødens realitet, « postulerer han, »så ville vi ikke forsøge at forene de to iagttagelser i et og samme begreb, tid.«" (Leach $1961 \mathrm{i}$ Nicolaisen 2004, 21-22).

Mens Leach og Gells pointer primært omhandler distinktionen mellem cyklisk og lineær tid, henviser de også til nogle andre dimensioner; nemlig det forhold at tid er noget, vi oplever og erfarer gennem vores sanser, for eksempel i den betydning at temporale dimensioner tillægger begivenheder mening. Slutningen af livet har en anden betydning eller mening end livets begyndelse, og arbejde i arbejdstid har en anden betydning end arbejde udført i fritiden. Ifølge Munn (1992) bør tid således også studeres som noget, der er indlejret i social praksis, hvor tid på en gang har socialt synkroniserende og koordinerende egenskaber. Tid er for eksempel nogle gange med til at organisere inkonsistente eller usam- 
menhængende elementer, som individer og samfund, følelser og tænkning, arbejde og fritid. Andre gange 'hjælper' tid individer og grupper med at udvikle identitet og forstå meningssammenhænge. Tid kan således bruges som et middel til at opnå bestemte mål. Dette ses tydeligt $i$ indretningen af vores arbejdsliv - herunder organiseringen af arbejdet i private og offentlige virksomheder og institutioner. Herved virker tid også disciplinerende - i foucauldiansk forstand - som en instans, der disciplinerer og strukturerer det moderne liv.. Helt overordnet giver det således både mening at se på tid som et fænomen, der tillægges en bestemt betydning (cyklisk eller lineær), men også som en social medspiller, der, indlejret i social praksis, har indflydelse på vores oplevelser af livsrytmer og på den måde, vi indretter vores liv og samfund på.

Artiklerne i dette nummer inddrager netop disse forskellige tidsperspektiver og demonstrerer, hvordan forestillinger om tid varierer, men altid er forankrede i sociale processer, livsforløb eller konkrete oplevelser; og i sig selv føder ind i sociale processer og tillægger, som illustreret i dette temnummer, sygdomsoplevelser og praksisser en særlig mening og betydning.

\section{At koble tid og kræft}

Kræft har de sidste ti år været genstand for stor politisk, offentlig og forskningsmæssig opmærksomhed i Danmark. Det har resulteret i en fremvækst af forskellige sundhedspolitiske tiltag (f.eks. kræftpakker, screeningsprogrammer, rehabiliteringstilbud, folkeoplysningskampagner), der delvist afspejles i en række forskningstemaer (f.eks. diagnostisk forsinkelse, screening, genetisk rådgivning og palliativ behandling, kræftorganisation) (fx Olesen et al., 2009; Probst et al. 2012), der alle har det til fælles, at de på forskellig vis fokuserer på og inddrager begrebet tid. Tid forstået i lineær form som tempo i diagnostik og behandling, hvilket primært handler om at mindske tiden til diagnosen og hermed potentielt udsætte døden. Der tales om ventetid, tidsdefinerede begivenheder, forløbstid, tidlig diagnostik, målrettet og tidsafgrænset rehabilitering, tidsmonitorering, tidsledelse osv., hvilket tydeligt indikerer, at tid indgår som struktureringsmekanisme i fx sundhedsprofessionelles varetagelse af pakkeforløb for kræftpatienter. Også den cykliske eller sociale dimension af tid er til stede i form af fx tid forstået som en afslutning, der kan forbedres af for eksempel en optimeret palliativ indsats. Eller tid, der sættes på standby i rehabiliteringsforløb, hvor patienter skal lære at leve med nye begrænsninger og udfordringer. 
Det er vores hensigt med dette nummer at bidrage med nye indsigter til relationen mellem tid og kræft. Både tid som et kulturelt fænomen, hvis betydning er omskiftelig (Gell 1992), men også tid som medspiller i det sociale landskab (Munn 1992), der har betydning for, hvordan vi tænker, organiserer og erfarer kræft. Dette er blandt andet tilfældet i Tørrings bidrag, hvor hun diskuterer, hvordan tid i 2000'erne fik betydning for samtidens kræftdiskurs og dermed for organiseringen af udredning og behandling. Vi har også eksempler på analyser, hvor tidslighed eller tid indgår som en relativ kategori, der ændrer sig i individers møde med kræft. Dette gør sig for eksempel gældende i Sachs analyse af genetisk rådgivning og dennes betydning for forståelse for kræftpatienters oplevelse af slægtskab. Det gør sig også gældende i Henriksens analyse af den atypiske rejse, hvor den arketypiske 'hjem'ud'hjem' figur sprænges til fordel for en rejse, hvis kurs og begivenheder er uforudsigelige.. Tid analyseres ligeledes i samspil med begivenheder, hvor tid i mere cyklisk forstand opleves som tiden før og efter kræftsygdommen og som en fremtidig temporalitet i form af håb om 'at udsætte døden'. Dette gør sig gældende i Ploug Hansen og Tjørnhøj-Thomsens analyser af samspillet mellem tid og håb og spores i Auskers beskrivelser af kræftramtes tilvalg af religiøsitet.

Udover den fælles tematik om tid har det også været redaktionens hensigt at samle et temanummer, der illustrerer nogle af samtidens centrale perspektiver og diskussioner om kræft. Som beskrevet af Sontag i slutningen af 1970'erne i hendes klassiske analyser af de sygdomsmetaforer, der knytter sig til tuberkulose og kræft, har kræft altid haft en mytologisk status (1977). Indhyllet i krigsmetaforik er den tilstede i vores erindringer og vores bevidsthed som en af menneskets værste fjender i det 20 århundredes, hvilket ikke mindst skyldes kræftens tidslige dimensioner.

"TB is a disease of time; it speeds up life, highlights it, spiritualizes it. In both English and French consumption "gallops". Cancer has stages rather than raits; it is (eventually) "terminal". Cancer works slowly, insidiously: the standard euphemism in obituaries is that someone has" died after a long illness" (Sontag 1977: 14).

"Cancer fills the role of an illness experienced as a ruthless, secret invasion - a role it will keep until, one day, its etiology becomes as clear and its treatment as effective as those of TB have become" (Sontag 1977: 5).

I modsætning til tuberkulose er vores forestillingsunivers om kræft, ifølge Sontag, fyldt med associationer til langsommelighed og død, som i udtrykket 'kræften kom snigende' og 'kræften dræber'. Mens Sontag blotlægger vores latente 
kræftfrygt, er hendes ærinde dog også en mere overordnet kultur- eller ætiologikritik af det tidlige 20. århundredes sammenkobling af kræft og 'psykologisk habitus'. En sammenkobling, der fejlagtigt tillægger den syge ansvar for at være blevet syg, og en kobling som blot lever i litteraturens og den almene forstålse af kræft, fordi vi har ringe indsigt i de reelle årsager til kræft. Kontrasten mellem tuberkulose og kræft i det ovenstående citat bør således også læses som et håb om at kræft, grundet bedre ætiologisk forståelse og bedre behandling, en dag vil blive afmystificeret (eller måske de-metaforiseret), som det skete for det 19. århundredes store folkesygdom, tuberkulosen. I forhold til en sammentænkning af tid og kræft leverer Sontag således en række pointer eller spådomme: at kræft er indhyllet i en tidsmetaforik, hvorigennem kræft primært afbildes som en langsom dræber, som man hverken kan besejre i slåskamp eller føre krig mod. Kræft kan behandles med moderne våben, men man ved ikke, om de virker rigtigt. Derfor er kræft også, ifølge Sontag, den fjende, som er tilbage, når al anden modstand i tiden er væk.

Det er svært at spå og ligeså svært at vurdere, hvorvidt Sondags spådom kan ydes retfærdighed her næsten 40 år senere. Sikkert er, at kvaliteten af kræftbehandlingen er væsentligt bedre i dag end tidligere. Langt flere overlever deres kræftsygdom (Statens Serum Institut, 2013), og moderne videnskab har efterhånden fået større indsigt $\mathrm{i}$ kræftætiologiens kompleksitet og diversitet; fx i samspillet mellem vira (fx HPV-virus) og kræft og genetikkens betydning for udviklingen af nogle kræftformer som brystkræft og kolonkræft. Hvorvidt det har ændret på kræftmetaforikken, som den udtrykkes i litteraturen eller folks fortællinger om kræft, vil fremtidig forskning have til gode at svare på. Nogle af artiklerne i dette nummer peger dog på, at kræft stadig betragtes som 'terminal' (Raunkier) eller forbindes med 'død, invasion og opbrud' (Ploug Hansen og Tjørnhøj-Thomsen). Og det foreslås, at tidsmetaforikken har ændret sig, så vi i dag i højere grad tænker på kræft som noget akut, der kræver en øjeblikkelig indsats (Tørring). Men netop anråbelsen af ordene 'akut' og 'øjeblikkelig indsats' er ikke uskyldig og påvirker vores opfattelse af virkeligheden. I Sontags forstand ledsages kræft derfor stadig i vor tid af katastrofemetaforer, der indebærer en næsten umenneskelig frygt og usikkerhed, for de, der rammes af sygdommen. Herved er vi tilbage ved koblingen af tid og kræft som ledsagende fænomener. 


\section{Om nummerets bidrag}

I temanummerets indledende bidrag beskriver Tørring det socio-politiske landskab, der op igennem nullerne resulterede i etableringen af nye forståelsesrammer omkring kræft. Særligt viser hun, hvordan et fokus på tid (igen) fik betydning for både vores forståelse af, hvad kræft er for en slags sygdom, men også for de tiltag, der førte til radikale ændringer af det danske sundhedsvæsen. Tørrings analyse er interessant, da den illustrerer den biomedicinske tænknings sociale og politiske forankring og giver et bud på, hvordan denne forankring etableres gennem konkret praksis.

Med Sachs bidrag flyttes vores perspektiv fra makrofortællinger om kræftdiskurser til en analyse af det sociale i en klassisk antropologisk forstand. Sachs leverer en samtidig (eller moderne) fortælling om slægtsskabets betydning. Ifølge Sachs etablerer kræftgenetisk rådgivning, og det hun kalder en medikalisering af slægtsskaber, en ny dynamik omkring slægtsskaber, hvor de implicerede parter ikke bare beslægtes (og for nogles vedkommende gen-beslægtes), de beslægtes også på en bestemt måde, nemlig gennem risiko og sygdom. Ifølge Sachs favner genetikken således klassiske forståelser af slægtsskab og sætter blod- eller vævsarv, som det benævnes i hendes bidrag, på dagsordenen i vor samtid, hvor blodslægsskabet $\mathrm{i}$ andre af livets dimensioner spiller en stadig mindre rolle. Tid inddrages her således som betragtninger over vores samtid, men også i en række analyser over genetikkens rolle i etableringen af blod- og familiebånd over tid; og med implicitte referencer til en cyklisk tidsforståelse i den forstand, at det er risikoens eller sygdommens genkomst, der står i centrum for det sociale.

Uden direkte at referere til Sontags forfatterskab, indskriver Raunkiær sig med sin artikel om professionelles forestillinger om palliativ indsats i en kritisk forskningstradition, der viser, hvorledes sygdomskategorisering har en determinerende effekt på henholdsvis de, som behandler sygdom, og de som henvender sig til behandlere for at få behandling af deres sygdom. Raunkjær har undersøgt, hvilke kategoriseringspraksisser - typisk retoriske - læger, sygeplejersker, socialog sundhedsassistenter og hjælpere bruger om palliative forløb for henholdsvis kræftpatienter, KOL og hjertepatienter. Til cancer er ordene 'terminal', 'rigtigt dårligt' og 'kompleks' typisk koblet til tidsforståelsen 'kortvarig', 'sidste tid' og 'begrænset tid'. Til KOL er omvendt koblet ord som 'lige efter bogen', 'nemt' og 'selvforskyldt' på tidsperspektivet 'længerevarende' og 'lang tid'. Disse kategoriseringspraksisser, mener forfatteren, har betydning for, hvem der a priori opfattes 
som alvorligt syge og palliationskrævende - nemlig kræftpatienter - og hvem der er overladt til sig selv, som eksempelvis KOL patienter.

I Ploug Hansen og Tjørnhøj-Thomsens bidrag vægtes kræftpatienternes egne stemmer. Gennem digte og etnografisk genererede cases fremskriver forfatterne 'stemninger, sanseindtryk, erkendelser og betydninger' og kobler herigennem betragtninger over tid og håb. Særligt beskrives kræftpatienters frygt for døden, håbet om dødens udsættelse og tanker om forgængelighed og usikkerhed, og læseren får et indblik $\mathrm{i}$, hvorledes disse udfoldes i hverdagslivets mikrokosmos. Forfatterne argumenterer blandt andet for, at gentagelse er en forudsætning for, at de syge oplever en form for stabilitet og normalitet, hvilket indebærer en genetablering af kroppens og hverdagslivets rytmer og rutiner. Tid i dette bidrag handler således både om udstrækning, det vil sige om at få mere tid at leve $\mathrm{i}$, men det beskrives også, hvorledes temporalitet gennem gentagelser og rytmer er med til at etablere håb gennem en fornemmelse af at være normal.

Med udgangspunkt i Baumans civilisationskritik viser religionssociologen $\mathrm{Au}-$ sker, hvordan religiøsitet i sygdomssituationer er en vare, der kan vælges til eller fra alt efter individets øjeblikkelige, oplevede behov, også kaldet 'Pro necessitate religiøsitet'. Som Ausker skriver, forbeholder kræftpatienter sig retten til at forbruge religiøsitet, som de vælger at forbruge andre varer. I tiden efter sygdom eller tilbagekomsten til et rask liv bliver religion typisk valgt fra, hvis patienten ikke tidligere i sit liv har været religiøst anlagt. Sagt med andre ord: 'Religiøsitet betyder måske særligt meget i brydningspunkter i menneskets liv, uden det betyder, at religion altid er til stede hos individer som isbjerget under vandet på andre tidspunkter' (Ausker: 109-110). Forfatteren argumenterer for, at vi må tage en ny tidsforståelse til os i forskningen af religiøsitet under sygdom. Frem for at tale om sygdom som et radikalt brud med et tidligere levet, stabilt liv, forstået som en lineær række af tidslige begivenheder, normer og værdier, er sygdom og den medfølgende religiøsitet blot et moment $\mathrm{i}$ en allerede flydende identitetsproces bestående af valg og tilvalg.

Henriksen viser på baggrund af en Bakhtin-inspireret analyse af den selvbiografiske kræftfortælling 'Vingefang' af forfatteren Liselotte Vendelboe Andersen, hvordan metaforen om 'kræften som en rejse' ofte bringes i centrum som metafor for den syges eksistentielle overvejelser, sorger og længsler. Dog opererer (kræft) rejsen i det analyserede værk med en anden kronotopisk forestilling end i populære kræftselvbiografier, og rejsen går alle andre veje end ligeud. Rejsemetaforen bliver hermed også et opgør med individets lineære opfattelse af tid, sted, fortælling og identitet. Et anslået tema undervejs er således ikke det identitetsbærende 
'hvem er jeg?', men snarere 'hvor er jeg?' i dette sygdomsland. Artikler konkluderer blandt andet - og her ender vi i samme kritiske position som Raunkiers studie - at 'de metaforer, genrer og diskurser, som indgår i den kulturelle italesættelse af kræftsygdomme, er langt fra neutrale eller 'uskyldige' (Henriksen: 137). De er tværtimod indlejret i komplekse kulturelle betydningsmønstre, som er medvirkende til at præge den måde, hvorpå sygdommen generelt anskues, italesættes og håndteres'.

Artiklerne i dette tidskrift viser således samstemmende, at tid og kræft samt et forskningsmæssigt fokus på koblingen imellem dem, åbner op for både interessante og originale analyser af vores samtid.

Tilbage er blot at ønske læseren god læselyst.

\section{Referencer}

Gell, A (1992). The Anthropology of Time: Cultural Constructions of Temporal Maps and Images. Oxford: Berg.

Miller, W M (2000). Durkheimian Time. Time \& Society (9)1.

Munn, N (1992). The Cultural Anthropology of Time: A Critical Essay. Annual Review of Anthropology. 21:93-123.

Nikolaisen, I (2004). Antropologiens tid - tidens antropologi. I: Spor af tid. Red. Bjørnness, Jeanette og Ostenfeld-Rosenthal, Ann. Aarhus: Department of Ethnography and Social Anthropology.

Olsen, F; Hansen RP; Vedsted, P. (2009). Delay in Diagnosis. The Experience in Denmark. British Journal of Cancer. 101:5-8

Probst, HB; Zubair, H; Andersen, O (2011). Cancer patient pathways in Denmark as a joint effort between bureaucrats, health professionals and politicians. A national Danish project. Health Policy; 105:65-70.

Statens Serum Institut (2013). Kræftoverlevelse i Danmark 1997-2011.

Sontag, S (1977). Illness as Metaphor. New York: Farrar, Straus and Giroux. 